Research Article

\title{
Method Development and Validation of Montelukast in API and Pharmaceutical Dosage form by UV Spectrophotometry
}

\author{
Abhishek Chandola*, Meenakshi Bhatt \\ Department of Pharmaceutical Chemistry, School of Pharmaceutical Sciences, \\ Shri Guru Ram Rai University, Patel Nagar, Dehradun, Uttarakhand, India. \\ *Corresponding author's E-mail: abhishekchandola813@gmail.com
}

Received: 03-10-2021; Revised: 22-11-2021; Accepted: 30-11-2021; Published on: 15-12-2021.

\begin{abstract}
\end{abstract}
The present work is done to develop a new simple, rapid, specific, accurate and precise UV spectrophotometric method for Montelukast as API and in pharmaceutical dosage form. The validation of the proposed method was carried out according to the I.C.H guidelines. The wavelength maxima was found $270 \mathrm{~nm}$ and calibration curves were obtained in the concentration range $5-45 \mu \mathrm{g} / \mathrm{ml}$ for montelukast with good correlation coefficients ( $r 2=0.9994$.). The precisions of the new method for montelukast was less than the maximum allowable limit (\%RSD <2.0) specified by the ICH. Therefore, the method was found to be an accurate, reproducible and sensitive for analysis of montelukast as standard, pharmaceutical dosage forms, and other routine analysis method.

Keywords: UV, Montelukast, Methanol, concentration range, correlation coefficient, Validation.

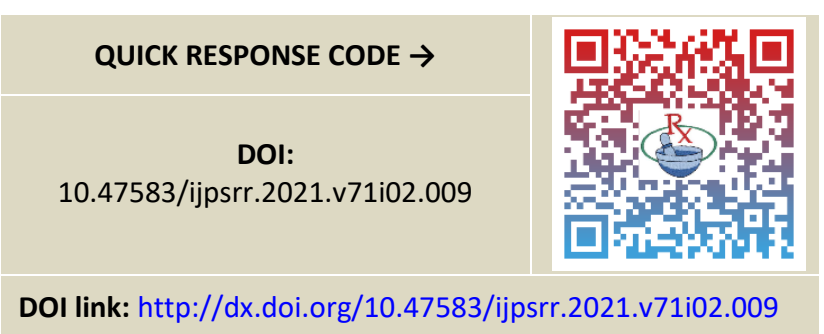

\section{INTRODUCTION}

M ontelukast is a leukotriene receptor antagonist used as part of an asthma therapy regimen, to prevent exercise induced bronchoconstriction, and to treat seasonal allergic rhinitis. ${ }^{16}$ Montelukast (empirical formula $\mathrm{C}_{35} \mathrm{H}_{35} \mathrm{ClNO}_{3} \mathrm{~S}$ ) is a highly selective leukotriene receptor antagonist that binds with high affinity to the cysteinyl leukotriene receptor for leukotrienes D4 and E4. These leukotrienes are excreted by various types of cells, such as mast cells, and are involved in the inflammatory process that may cause the signs and symptoms of asthma and allergic rhinitis. Leukotriene receptors are found in airway cells, such as macrophages and smooth muscle cells. When bound to leukotriene receptors, montelukast inhibits leukotriene physiologic effects (such as airway edema, smooth muscle contraction, and impairment of normal cellular activity) without exhibiting any agonist activity. ${ }^{17}$

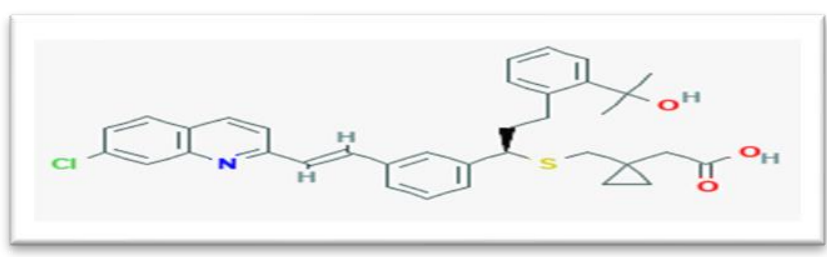

Figure 1: Molecular structure of Montelukast

\section{MATERIALS AND METHODS}

\section{Instrument Used}

The spectrophotometric analysis was carried out on Single beam UV spectrophotometer (GS2281) using $1 \mathrm{~cm}$ quartz cell. The application software used for the obtaining the spectra was named CaryWin60 and is manufactured by Agilent Tech. All weighing was carried out on single pan Digital weighing balance (TX323L) manufactured by Shimadzu Instrument Pvt. Ltd.

\section{Chemical Used}

Montelukast with claimed purity was obtained as a gift sample from the Synokem Pharmaceuticals, Haridwar. Montair 10mg (Marketed formulation) was purchased from the local market. Methanol (analytical reagent grade) was obtained from central drug house Pvt. Ltd.

\section{Method Development For Estimation of Montelukast by UV-Spectrophotometry}

\section{Preparation of Standard Stock Solution}

Stock solutions of was prepared by transferring $50 \mathrm{mg}$ of the drug in $50 \mathrm{ml}$ volumetric flask and dissolved in $30 \mathrm{ml}$ of methanol and the volume was made up to the mark with methanol. This standard stock solution contains $1000 \mu \mathrm{g}$ of drug per $\mathrm{ml}$. $5 \mathrm{ml}$ of this solution was transferred to additional $50 \mathrm{ml}$ volumetric flask and further diluted up to $50 \mathrm{ml}$ mark with methanol. This standard solution contains $100 \mu \mathrm{g}$ of drug per $\mathrm{ml}$ (working standard stock).

\section{Selection of wavelength Maxima ( $\lambda$ max)}

Pipette out $1 \mathrm{ml}$ of working standard solution and transfer into $10 \mathrm{ml}$ volumetric flask and the volume was made up to the mark with solvent to get the concentration 10 $\mu \mathrm{g} / \mathrm{ml}$. The resulted $10 \mu \mathrm{g} / \mathrm{ml}$ solution was scanned in UVSpectrophotometer between 200-400 nm using methanol 
as blank. The wavelength maxima were established at $270 \mathrm{~nm}$. The results are shown in figure 1.

\section{Preparation of Calibration curve}

Pipette out $0.5,1,1.5,2,2.5,3,3.5,4$ and $4.5 \mathrm{ml}$ working standard solution and transfer into nine separate $10 \mathrm{ml}$ volumetric flasks and made the volume all of them to 10 $\mathrm{ml}$ with methanol to get the concentrations 5, 10, $15,20,25,30,35,40$ and $45 \mu \mathrm{g} / \mathrm{ml}$ respectively. Absorbance of the resultant solution was measured at $270 \mathrm{~nm}$ using methanol as blank. A graph was plotted between the concentrations and their respective absorbance. The response of the drug was found linear in the entire investigational range of $5-45 \mu \mathrm{g} / \mathrm{ml}$. The calibration equation for montelukast the calibration curve equation obtained was found to be $y=0.0242 x-0.0302$ with 0.9994 correlation coefficient.

\section{Repeatability}

Pipette out 2, 2.5, $3 \mathrm{ml}$ standard solution and transfer into a series of nine, $10 \mathrm{ml}$ volumetric flasks. Dilute it to $10 \mathrm{ml}$ with methanol to get $20,25,30 \mu \mathrm{g} / \mathrm{ml}$ solutions respectively. Absorbance of the resultant solutions was measured at $270 \mathrm{~nm}$ using methanol as blank. The result obtained and summarized in the table 2 .

\section{Intra-Day Precision}

Pipette out 2, 2.5 and $3 \mathrm{ml}$ working solution and transfer into separate $10 \mathrm{ml}$ volumetric flasks and made up the volume to $10 \mathrm{ml}$ with methanol to get the concentrations 20,25 and $30 \mu \mathrm{g} / \mathrm{ml}$ respectively. Absorbance of the resultant solutions was measured at $270 \mathrm{~nm}$ using methanol as blank. Such three revisions were performed within a day at $3 \mathrm{hrs}$ interval. The result was summarized in the table 3 .

\section{Inter-Day Precision}

Pipette out 2, 2.5 and $3 \mathrm{ml}$ working solution and transfer into separate $10 \mathrm{ml}$ volumetric flasks. Dilute all of them to $10 \mathrm{ml}$ with methanol to get solution of concentrations 20, 25 and $30 \mu \mathrm{g} / \mathrm{ml}$ respectively. Absorbance of the resultant solutions was measured at $270 \mathrm{~nm}$ using methanol as blank. Such three studies were performed for day one, day two, day three intervals. The result was summarized in the table 4.

\section{Accuracy}

Pipette out $2 \mathrm{ml}$ standard solution and transfer into $10 \mathrm{ml}$ volumetric flasks. Nine such transfers were made. Spike three of volumetric flask with the solutions with $1.6 \mathrm{ml}$ of working solution (Prepared from Formulation) and dilute each to $10 \mathrm{ml}$ with methanol to get $16 \mu \mathrm{g} / \mathrm{ml}$ solutions. Spike another three of the solutions with $2 \mathrm{ml}$ of working solution and dilute each to $10 \mathrm{ml}$ with methanol to get $20 \mu \mathrm{g} / \mathrm{ml}$ solutions. Spike last three of the solutions with $2.4 \mathrm{ml}$ of working solution and dilute each to $10 \mathrm{ml}$ with methanol to get $24 \mu \mathrm{g} / \mathrm{ml}$ solutions. Absorbance of the resultant solutions was measured at $270 \mathrm{~nm}$ using methanol as blank. The obtained results were summarized in the table 5.

\section{Specificity}

Specificity study was carried out by observing any interference in absorbance of drug in the presence of common excipients like starch, talc, lactose, magnesium stearate etc. Absorbance of $20 \mu \mathrm{g} / \mathrm{ml}$ drug solution with and without excipients was measured at $270 \mathrm{~nm}$ using methanol as blank. The results obtained were summarized in the table 6.

\section{Limit of Detection (LOD)}

The Detection Limit is defined as the lowest concentration of an analyte in a sample that can be detected.

The Detection Limit may be expressed as:

$$
\begin{aligned}
& \mathrm{DL}=3.3 \sigma / \mathrm{s} \\
& \mathrm{DL}=\mathbf{2 . 7 5 5 9 0 9}
\end{aligned}
$$

Where,

$\sigma=$ standard deviation of the response.

$\mathrm{s}=$ slope of the linearity curve.

\section{Limit of Quantitation (LOQ)}

The Quantitation Limit is the lowest concentration of an analyte in a sample that can be determined with acceptable precision and accuracy under the stated operational conditions of the analytical procedures.

The Quantitation Limit may be expressed as:

$$
\begin{aligned}
& Q L=10 \sigma / s \\
& Q L=8.31524
\end{aligned}
$$

Where,

$\sigma=$ standard deviation of the response.

$S=$ slope of the linearity curve.

Estimation of Montelukast in pharmaceutical dosage form (Montair 10mg)

Weigh 10 tablets and calculate the average weight of the tablets. Powered the tablets and weigh accurately a quantity of powdered containing about $50 \mathrm{mg}$ of montelukast and transfer it into $50 \mathrm{ml}$ volumetric flask and add $30 \mathrm{ml}$ methanol, sonication for 10 minutes and made up the volume to $50 \mathrm{ml}$ with solvent then mix and filter that solution. Taken $5 \mathrm{ml}$ of the filtrate and made up the volume to $50 \mathrm{ml}$ with methanol. Further dilute $1 \mathrm{ml}$ of the resulting solution to $10 \mathrm{ml}$ with methanol. Measure the absorbance of this resulting solution at $270 \mathrm{~nm}$. The above procedure was repeated for three times. The result obtained was summarized in the table 7 . 


\section{RESULTS}

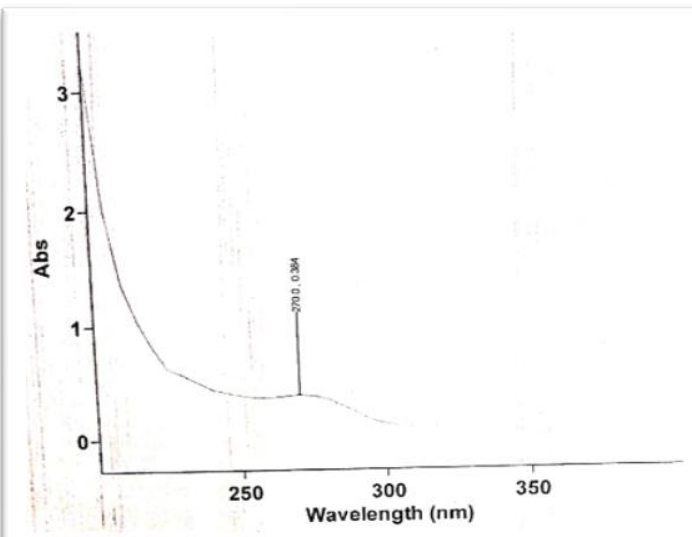

Figure 1: Wavelength maxima of Montelukast in Methanol

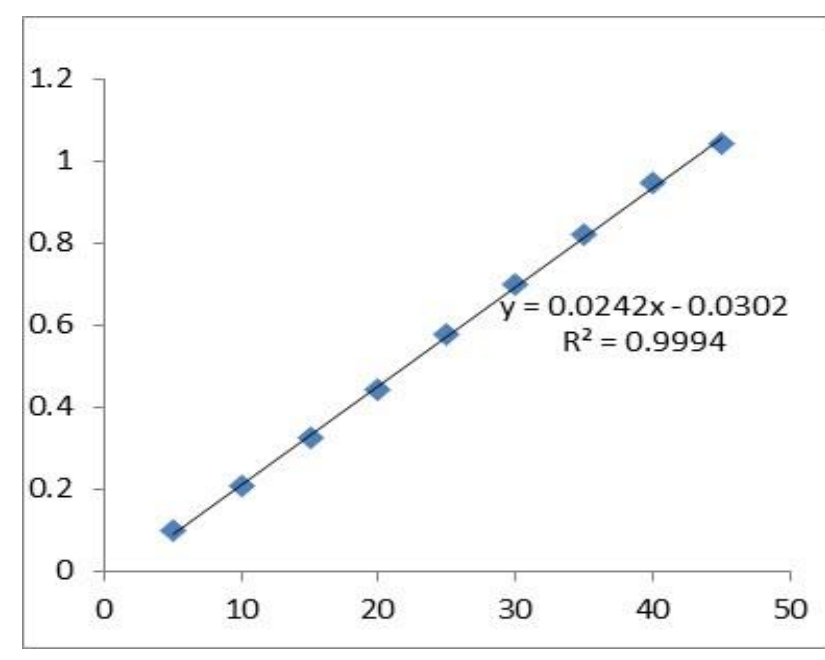

Figure 2: Calibration curve of Montelukast in Methanol

Table 1: Linearity, $\mathrm{E}^{1 \%}{ }_{1 \mathrm{~cm}}$, Absorptivity ( $\left.\mathrm{Lgm}-1 \mathrm{~cm}-1\right)$, Molar Absorptivity (L mol-1 cm-1) of Montelukast

\begin{tabular}{|c|c|c|c|c|c|}
\hline S. No & $\begin{array}{l}\text { CONCENTRATION } \\
(\mu \mathrm{g} / \mathrm{ml})\end{array}$ & ABSORBANCE at $270 \mathrm{~nm}$ & $\mathrm{E}^{1 \%}{ }_{1 \mathrm{~cm}}$ & ABSORPTIVITY & MOLAR ABSORPTIVITY \\
\hline 1 & 5 & 0.0989 & 197.8 & 19.78 & 11606.42 \\
\hline 2 & 10 & 0.2069 & 206.9 & 20.69 & 12128.13 \\
\hline 3 & 15 & 0.3266 & 217.7 & 21.77 & 12761.20 \\
\hline 4 & 20 & 0.4432 & 221.6 & 22.16 & 12989.82 \\
\hline 5 & 25 & 0.5766 & 230.6 & 23.06 & 13517.38 \\
\hline 6 & 30 & 0.7012 & 233.7 & 23.37 & 13699.09 \\
\hline 7 & 35 & 0.8207 & 234.5 & 23.45 & 13745.99 \\
\hline 8 & 40 & 0.9465 & 236.6 & 23.66 & 13869.09 \\
\hline \multirow[t]{2}{*}{9} & 45 & 1.0452 & 232.3 & 23.23 & 13617.03 \\
\hline & & Mean & 223.5 & 22.35 & 13103.79 \\
\hline
\end{tabular}

Table 2: Study of Repeatability

\begin{tabular}{|c|c|c|c|c|c|}
\hline $\begin{array}{l}\text { Concentration } \\
(\mu \mathrm{g} / \mathrm{ml})\end{array}$ & Absorbance & $\begin{array}{l}\text { Observed Concentration } \\
\qquad(\mu \mathrm{g} / \mathrm{ml})\end{array}$ & $\begin{array}{c}\text { Mean } \\
\text { Concentration }\end{array}$ & SD & \%RSD \\
\hline $20 \mu \mathrm{g} / \mathrm{ml}$ & $\begin{array}{l}0.4634 \\
0.4610 \\
0.4360\end{array}$ & $\begin{array}{l}20.3 \mu \mathrm{g} / \mathrm{ml} \\
20.2 \mu \mathrm{g} / \mathrm{ml} \\
19.8 \mu \mathrm{g} / \mathrm{ml}\end{array}$ & $20.1 \mu \mathrm{g} / \mathrm{ml}$ & 0.2645 & 1.3162 \\
\hline $25 \mu \mathrm{g} / \mathrm{ml}$ & $\begin{array}{l}0.5744 \\
0.5722 \\
0.5688\end{array}$ & $\begin{array}{l}24.9 \mu \mathrm{g} / \mathrm{ml} \\
24.8 \mu \mathrm{g} / \mathrm{ml} \\
24.6 \mu \mathrm{g} / \mathrm{ml}\end{array}$ & $24.76 \mu \mathrm{g} / \mathrm{ml}$ & 0.1529 & 0.5938 \\
\hline \multirow[t]{2}{*}{$30 \mu \mathrm{g} / \mathrm{ml}$} & $\begin{array}{l}0.6999 \\
0.6871 \\
0.6772\end{array}$ & $\begin{array}{l}30.1 \mu \mathrm{g} / \mathrm{ml} \\
29.6 \mu \mathrm{g} / \mathrm{ml} \\
29.3 \mu \mathrm{g} / \mathrm{ml}\end{array}$ & $29.66 \mu \mathrm{g} / \mathrm{ml}$ & 0.4044 & 1.3628 \\
\hline & & Mean & & & 1.1062 \\
\hline
\end{tabular}

Table 3: Study of Intra Day Precision

\begin{tabular}{|c|c|c|c|c|c|c|c|c|c|}
\hline \multirow[t]{2}{*}{ Conc. $(\mu \mathrm{g} / \mathrm{ml})$} & \multicolumn{3}{|c|}{ Absorbance } & \multicolumn{3}{|c|}{ Observed Concentration $(\mu \mathrm{g} / \mathrm{ml})$} & \multirow[t]{2}{*}{ Mean } & \multirow[t]{2}{*}{ SD } & \multirow[t]{2}{*}{ RSD } \\
\hline & Ohrs & 3hrs & $6 \mathrm{hrs}$ & Ohrs & $3 \mathrm{hrs}$ & $6 \mathrm{hrs}$ & & & \\
\hline $20 \mu \mathrm{g} / \mathrm{ml}$ & 0.4610 & 0.4640 & 0.4626 & $20.2 \mu \mathrm{g} / \mathrm{ml}$ & $20.3 \mu \mathrm{g} / \mathrm{ml}$ & $20.3 \mu \mathrm{g} / \mathrm{ml}$ & $20.26 \mu \mathrm{g} / \mathrm{ml}$ & 0.0583 & 0.2878 \\
\hline $25 \mu \mathrm{g} / \mathrm{ml}$ & 0.5744 & 0.5728 & 0.5673 & $24.9 \mu \mathrm{g} / \mathrm{ml}$ & $24.8 \mu \mathrm{g} / \mathrm{ml}$ & $24.6 \mu \mathrm{g} / \mathrm{ml}$ & $24.75 \mu \mathrm{g} / \mathrm{ml}$ & 0.1541 & 0.6226 \\
\hline $30 \mu \mathrm{g} / \mathrm{ml}$ & 0.6988 & 0.6871 & 0.6797 & $30.1 \mu \mathrm{g} / \mathrm{ml}$ & $29.6 \mu \mathrm{g} / \mathrm{ml}$ & $29.3 \mu \mathrm{g} / \mathrm{ml}$ & $29.66 \mu \mathrm{g} / \mathrm{ml}$ & 0.5844 & 1.9705 \\
\hline \multicolumn{9}{|c|}{ Mean } & 0.9603 \\
\hline
\end{tabular}


Table 4: Study of Inter Day Precision

\begin{tabular}{|c|c|c|c|c|c|c|c|c|c|}
\hline \multirow{2}{*}{$\begin{array}{l}\text { Conc. } \\
(\mu \mathrm{g} / \mathrm{ml})\end{array}$} & \multicolumn{3}{|c|}{ Absorbance } & \multicolumn{3}{|c|}{ Observed Concentration $(\mu \mathrm{g} / \mathrm{ml})$} & \multirow[t]{2}{*}{ Mean } & \multirow[t]{2}{*}{ SD } & \multirow[t]{2}{*}{ RSD } \\
\hline & Ohrs & $24 \mathrm{hrs}$ & $48 \mathrm{hrs}$ & Ohrs & $24 \mathrm{hrs}$ & 48hrs & & & \\
\hline $20 \mu \mathrm{g} / \mathrm{ml}$ & 0.4640 & 0.4631 & 0.4365 & $20.3 \mu \mathrm{g} / \mathrm{ml}$ & $20.2 \mu \mathrm{g} / \mathrm{ml}$ & $19.8 \mu \mathrm{g} / \mathrm{ml}$ & $20.1 \mu \mathrm{g} / \mathrm{ml}$ & 0.2345 & 1.1667 \\
\hline $25 \mu \mathrm{g} / \mathrm{ml}$ & 0.5744 & 0.5722 & 0.5673 & $24.9 \mu \mathrm{g} / \mathrm{ml}$ & $24.8 \mu \mathrm{g} / \mathrm{ml}$ & $24.6 \mu \mathrm{g} / \mathrm{ml}$ & $24.76 \mu \mathrm{g} / \mathrm{ml}$ & 0.1529 & 0.6178 \\
\hline $30 \mu \mathrm{g} / \mathrm{ml}$ & 0.6984 & 0.6860 & 0.6780 & $30.1 \mu \mathrm{g} / \mathrm{ml}$ & $29.6 \mu \mathrm{g} / \mathrm{ml}$ & $29.3 \mu \mathrm{g} / \mathrm{ml}$ & $29.66 \mu \mathrm{g} / \mathrm{ml}$ & 0.4042 & 1.3628 \\
\hline \multicolumn{9}{|c|}{ Mean } & 1.0491 \\
\hline
\end{tabular}

Table 5: Study of Accuracy

\begin{tabular}{|c|c|c|c|c|}
\hline Recovery at & Nominal Conc. $(\mu \mathrm{g} / \mathrm{ml})$ & Absorbance & Observed Conc. $(\mu \mathrm{g} / \mathrm{ml})$ & \% Recovery \\
\hline $80 \%$ & $20+16=36 \mu \mathrm{g} / \mathrm{ml}$ & 0.8427 & 36.1 & $100.27 \%$ \\
\hline $80 \%$ & $20+16=36 \mu \mathrm{g} / \mathrm{ml}$ & 0.8321 & 35.6 & $98.88 \%$ \\
\hline $80 \%$ & $20+16=36 \mu \mathrm{g} / \mathrm{ml}$ & 0.8467 & 36.2 & $100.55 \%$ \\
\hline $100 \%$ & $20+20=40 \mu \mathrm{g} / \mathrm{ml}$ & 0.9228 & 39.8 & $99.50 \%$ \\
\hline $100 \%$ & $20+20=40 \mu \mathrm{g} / \mathrm{ml}$ & 0.9300 & 39.9 & $99.75 \%$ \\
\hline $100 \%$ & $20+20=40 \mu \mathrm{g} / \mathrm{ml}$ & 0.9310 & 40 & $100 \%$ \\
\hline $120 \%$ & $20+24=44 \mu \mathrm{g} / \mathrm{ml}$ & 1.0390 & 43.9 & $99.77 \%$ \\
\hline $120 \%$ & $20+24=44 \mu \mathrm{g} / \mathrm{ml}$ & 1.0410 & 44 & $100 \%$ \\
\hline $120 \%$ & $20+24=44 \mu \mathrm{g} / \mathrm{ml}$ & 1.0425 & 44.2 & $100.45 \%$ \\
\hline
\end{tabular}

Table 6: Study of Specificity

\begin{tabular}{|c|c|c|c|c|c|}
\hline Nominal Conc. $(\mu \mathrm{g} / \mathrm{ml})$ & \multicolumn{2}{|c|}{ Without Excipient } & \multicolumn{2}{c|}{ With Excipients } & \%Interference \\
\hline & Absorbance & $\begin{array}{c}\text { Observed } \\
\text { Concentration }\end{array}$ & Absorbance & $\begin{array}{c}\text { Observed } \\
\text { concentration }\end{array}$ \\
\hline $20 \mu \mathrm{g} / \mathrm{ml}$ & 0.4606 & $20.1 \mu \mathrm{g} / \mathrm{ml}$ & 0.4610 & 20.3 & 0.086 \\
\hline $20 \mu \mathrm{g} / \mathrm{ml}$ & 0.4600 & $20 \mu \mathrm{g} / \mathrm{ml}$ & 0.4605 & 20.2 & 0.108 \\
\hline $20 \mu \mathrm{g} / \mathrm{ml}$ & 0.4595 & $20 \mu \mathrm{g} / \mathrm{ml}$ & 0.4602 & 20.1 & 0.152 \\
\hline $20 \mu \mathrm{g} / \mathrm{ml}$ & 0.4553 & $19.9 \mu \mathrm{g} / \mathrm{ml}$ & 0.4560 & 20 & 0.154 \\
\hline $20 \mu \mathrm{g} / \mathrm{ml}$ & 0.4554 & $19.9 \mu \mathrm{g} / \mathrm{ml}$ & 0.4559 & 20 & 0.109 \\
\hline $20 \mu \mathrm{g} / \mathrm{ml}$ & 0.4600 & $20 \mu \mathrm{g} / \mathrm{ml}$ & 0.4606 & 20.3 & 0.103 \\
\hline
\end{tabular}

Table7: \%Assay of Montelukast in pharmaceutical dosage form (Montair, $10 \mathrm{mg}$ )

\begin{tabular}{|c|c|c|c|c|c|c|c|c|}
\hline S. No. & Absorbance & $\begin{array}{c}\text { Nominal } \\
\text { Conc. } \\
(\mu \mathrm{g} / \mathrm{ml})\end{array}$ & $\begin{array}{c}\text { Observed } \\
\text { Conc. } \\
(\mu \mathrm{g} / \mathrm{ml})\end{array}$ & $\begin{array}{c}\text { Dilution } \\
\text { Factor }\end{array}$ & $\begin{array}{c}\text { Weight } \\
\text { Taken } \\
(\mathbf{m g})\end{array}$ & $\begin{array}{c}\text { Average } \\
\text { Weight } \\
(\mathbf{m g})\end{array}$ & $\begin{array}{c}\text { Label } \\
\text { Claim } \\
(\mathbf{m g})\end{array}$ \\
\hline 1 & 0.4598 & $20 \mu \mathrm{g} / \mathrm{ml}$ & $20.1 \mu \mathrm{g} / \mathrm{ml}$ & 5000 & $246.8 \mathrm{mg}$ & $144.7 \mathrm{mg}$ & $10 \mathrm{mg}$ & $101 \%$ \\
\hline 2 & 0.4545 & $20 \mu \mathrm{g} / \mathrm{ml}$ & $19.8 \mu \mathrm{g} / \mathrm{ml}$ & 5000 & $246.8 \mathrm{mg}$ & $144.7 \mathrm{mg}$ & $10 \mathrm{mg}$ & $99 \%$ \\
\hline 3 & 0.4566 & $20 \mu \mathrm{g} / \mathrm{ml}$ & $20 \mu \mathrm{g} / \mathrm{ml}$ & 5000 & $246.8 \mathrm{mg}$ & $144.7 \mathrm{mg}$ & $10 \mathrm{mg}$ & $100 \%$ \\
\hline 4 & 0.4553 & $20 \mu \mathrm{g} / \mathrm{ml}$ & $19.9 \mu \mathrm{g} / \mathrm{ml}$ & 5000 & $246.8 \mathrm{mg}$ & $144.7 \mathrm{mg}$ & $10 \mathrm{mg}$ & $99.5 \%$ \\
\hline
\end{tabular}




\section{RESULTS AND DISCUSSION}

The pronounced method has been developed and validated for, accuracy, repeatability, specificity and precision. The nominal concentration of standard solutions was approximately $5-45 \mu \mathrm{g} / \mathrm{ml}$. The proposed method was found to be linear with a linear correlation coefficient 0.9994 of and the linear regression Equation, $y=0.0242 x-$ 0.0302 (fig.3). The linearity of concentration levels at which can be reliably $5-45 \mu \mathrm{g} / \mathrm{ml}$. The mean recoveries were $99.91 \%$ method as accurate (Table 5). The repeatability, intraday, inter-day precision, specificity, and accuracy, (RSD) was less than $2 \%$. Potency assay of dosage forms were performed by the proposed method. The brand products met the standard criteria with the new analytical method. Specificity is the ability of the reported method provides data on specificity for their estimation in the presence of formulation excipients. The absorbance obtained with the mixture of the excipients showed no interference with the absorbance of standard. The percent assays of Montelukast were found $99.87 \%$ in marketed product (Montair 10mg) in Table 7.

\section{REFERENCES}

1. T Soudi A, G Hussein O, S Elzanfaly E, E Zaazaa H, Abdelkawy M. Potentiometric method to determine Montelukast sodium in its tablets with in-line monitoring of its dissolution behaviour. Analytical and Bioanalytical Electrochemistry. 2020 Apr 30; 12(4): 502-16.

2. El Gamal R, El Abass SA, Elmansi HM. Quick simultaneous analysis of bambuterol and montelukast based on synchronous spectrofluorimetric technique. Royal Society Open Science. 2020 Dec 9; 7(12): 201156.

3. Sawatdee S, Nakpheng T, Yi BT, Shen BT, Nallamolu S, Srichana T. Formulation development and in-vitro evaluation of montelukast sodium pressurized metered dose inhaler. Journal of Drug Delivery Science and Technology. 2020 Apr 1; 56: 101534.

4. Kumar Raja Jayavarapu, Gaddala Swathi1, Jemema Thomas, Talla Gopi. Accurate and simple UV spectrophotometric method foe estimation of montelukast sodium in pure and marketed formulations. J. Global Trends Pharm Sci, 2017; 8(2): $3994-3997$.

5. Phadtare DG, Pawar AR, Kulkarni RR, Patil GK. Method development and validation of Montelukast sodium in bulk and tablet formulation by HPLC. Asian Journal of Research in Chemistry. 2016; 9(7): 339-42.
6. Singh K, Bagga P, Shakya P, Kumar A, Khalid M, Akhtar J, Arif $M$. Validated UV spectroscopic method for estimation of montelukast sodium. IJPSR. 2015 Nov 1; 6: 4728-32.

7. Savsani JJ, Goti PP, Patel PB. Simultaneous UV spectrophotometric method for estimation of Ebastine and Montelukast sodium in tablet dosage form by Q-ratio method. Int J Chem Tech Res. 2013; 5(1): 47-55.

8. Thesia UD, Patel PB. Stability Indicating HPLC Method Development for Estimation of Montelukast Sodium and Acebrophylline in Combined Dosage Form. Inventi Rapid: Pharm Analysis \& Quality Assurance. 2013 May 17.

9. Tandulwadkar SS, More SJ, Rathore AS, Nikam AR, Sathiyanarayanan L, Mahadik KR. Method development and validation for the simultaneous determination of fexofenadine hydrochloride and montelukast sodium in drug formulation using normal phase high-performance thin-layer chromatography. International Scholarly Research Notices. 2012; 2012.

10. Pallavi K, Babu S. Validated UV Spectroscopic method for estimation of Montelukast sodium from bulk and tablet formulations. International Journal of Advances in Pharmacy, Biology and Chemistry. 2012 Oct; 1(4).

11. Challa BR, Awen BZ, Chandu BR, Khagga M, Kotthapalli CB. Method development and validation of montelukast in human plasma by HPLC coupled with ESI-MS/MS: application to a bioequivalence study. Scientia pharmaceutica. 2010 Sep; 78(3): 411-2.

12. Mend H.J., et al., Vogel's, "Textbook Quantitative Chemical Analysis", 5th edition pearson education (Singapore) Pvt. Ltd. Indian branch, Delhi, 2003; Page 3-8, 630.

13. Skoog D.A., Holler F.J., et al., "Introduction to UV Spectroscopy in principle of Instrumental Analysis", 5th Edition, Thomson Brooks Cole Publication, 2004; Page 1-17, 301.

14. Sharma Y.R., "Ultravoilet and visible Spectroscopy in elementary organic spectroscopy", 1st edition, S. Chand \& Company Ltd, New Delhi, 2004; Page 9-60.

15. Willard H.H., et al, "Instrumental method of analysis", 7th Edition, New Delhi, CBS Publishers and Distributors,1988; Page 118-139.

16. Text on Validation of analytical procedure Q2B in; $I C H$ Harmonized Tripartite Guidelines, 1996; Page 7-13.

17. https://go.drugbank.com/drugs/DB00471

18. https://www.ncbi.nlm.nih.gov/books/NBK459301

Source of Support: The author(s) received no financial support for the research, authorship, and/or publication of this article.

Conflict of Interest: The author(s) declared no potential conflicts of interest with respect to the research, authorship, and/or publication of this article.

For any question relates to this article, please reach us at: editor@globalresearchonline.net New manuscripts for publication can be submitted at: submit@globalresearchonline.net and submit_ijpsrr@rediffmail.com 